\title{
Temperature Measurement of Polyethylene Exposed to Partial Discharge
}

\author{
Tatsunobu Ichiyanagi Member (Nihon University) \\ Tomoyasu Hayakawa Member (Nihon University)
}

Keywords : polyethylene, temperature measurement, partial discharge, X-ray diffractometer

In this paper, we measured the temperature of a polyethylene resin exposed to partial discharge.

Polyethylene (PE) resin is known to be a crystalline polymer that can adopt a folded chain conformation. With increased temperature, the molecular chains move and the PE transforms from the crystalline state that exits before heating.

Fig.1 was a characteristics of PE temperature vs the diffracted intensity using an X-ray diffractometer based on the fact that thermal vibration of the polyethylene molecules.

Parallel plate electrodes (two glass plates with an aperture in between) were attached to the goniometer of the X-ray diffractometer to generate partial discharge in Fig.2. A discharge was generated by applying a PE film to each glass plate electrode and the change in diffracted intensity was recorded in Fig.3.

The discharge was found to increase the temperature of the PE film by about 16 degrees above room temperature. This temperature rise is considered an average value resulting from penetration of the PE film by X-rays.

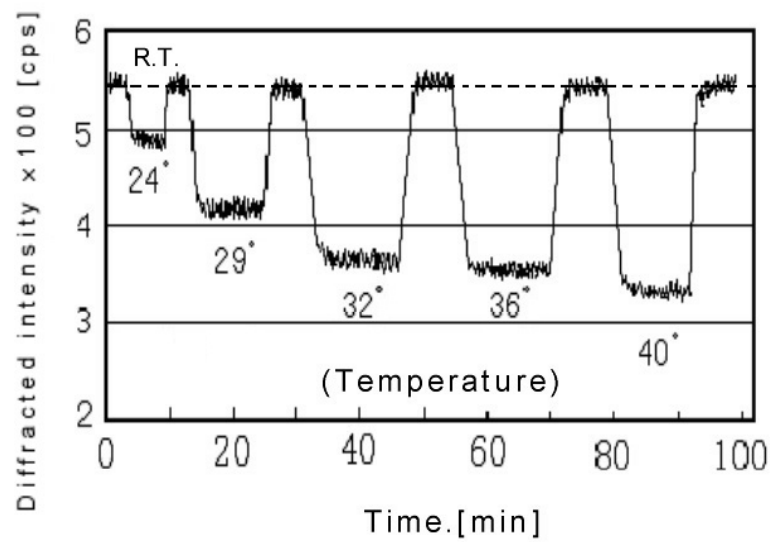

Fig. 1. Characteristics of tenperature vs. diffracted sintensity

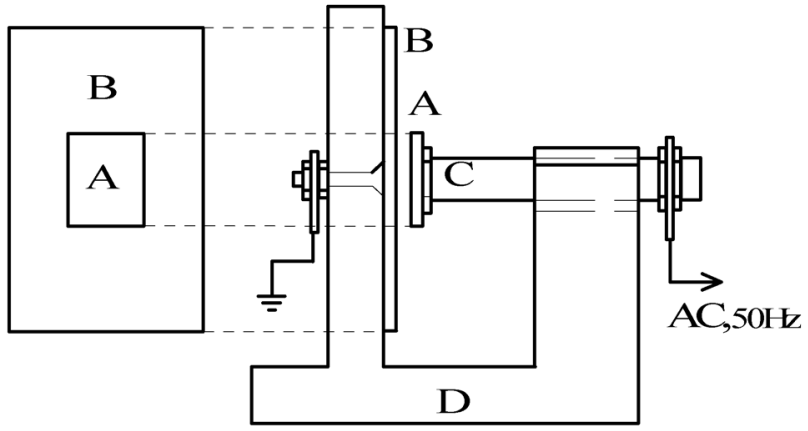

Fig. 2. A composition of a partial discharge electrode (A,B: glass plate, C:conductor)

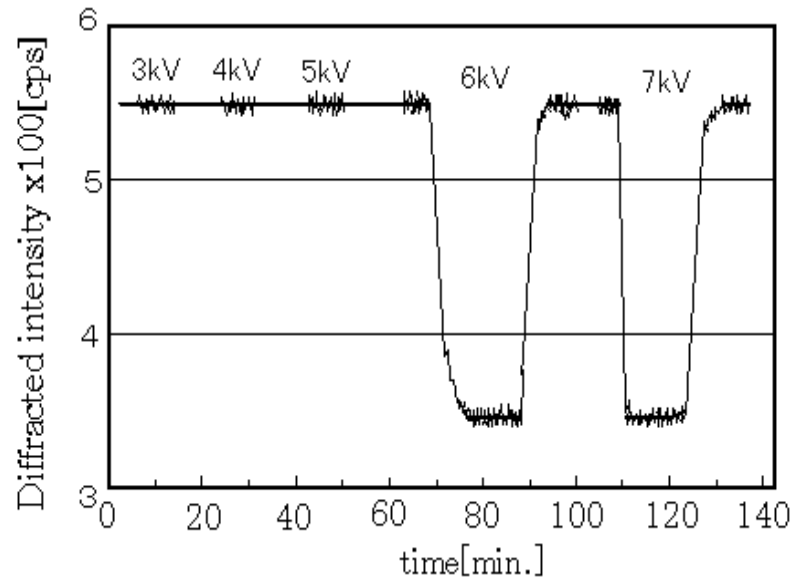

Fig. 3. Characteristics of voltage vs. the diffracted intensity 


\title{
部分放電に曝されたポリエチレンの温度測定 \\ 正 一柳 龍伸* 正 員 早川 朝康* \\ Temperature Measurement of Polyethylene Exposed to Partial Discharge
}

Tatsunobu Ichiyanagi*, Member, Tomoyasu Hayakawa*, Member

\begin{abstract}
We measured the temperature of a polyethylene film exposed to partial discharge using an X-ray diffractometer based on the fact that thermal vibration of the polyethylene molecules attenuates the diffracted intensity exponentially. Polyethylene (PE) resin is known to be a crystalline polymer that can adopt a folded chain conformation. In bulk, PE is composed of amorphous and crystalline regions. With increased temperature, the molecular chains move and the PE transforms from the crystalline state that exists before heating. When a film temperature was at less than 60 degrees above room temperature, the diffracted intensity was at the same value as at room temperature.

Parallel plate electrodes (two glass plates with an aperture in between) were attached to the goniometer of the X-ray diffractometer to generate partial discharge. Discharge by the electrodes only did not change the diffracted intensity. As such, the effect of X-ray dispersion by the electric field or discharge-generated gas was considered. A discharge was generated by applying a PE film to each glass plate electrode and the change in diffracted intensity was recorded. After the discharge had stopped, the PE film was heated to determine the temperature which gave the same diffracted intensity as that obtained by discharge. The discharge was found to increase the temperature of the PE film by 16 degrees above room temperature. This temperature rise is considered an average value resulting from penetration of the PE film by X-rays.
\end{abstract}

キーワード : ポリエチレン, 温度測定, 部分放電, $\mathrm{X}$ 線回折

Keywords : polyethylene, temperature measurement, partial discharge, X-ray diffractometer

\section{1. まえがき}

空気中の放電によって発生するガスの温度は堀井ら ${ }^{(1)}$ よると光のスペクトルから $710 \sim 880 \mathrm{~K}\left(437 \sim 607^{\circ} \mathrm{C}\right)$ と報 告されている。一般的なポリエチレン樹脂の融点および分 解温度は，それぞれ $110 \sim 130^{\circ} \mathrm{C}$ おび $400^{\circ} \mathrm{C}$ 程度であるか ら，ポリエチレンは放電ガスによって溶融および分解され てしまう。部分放電に暴露された電気絶縁材料の温度を計 測する方法には, IEC の棒一平板電極（空気の間隙を持たな

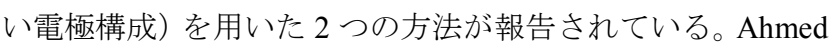
$ら^{(2)}$ は, 絶縁材料内に熱電対を埋設して求めた。平林ら ${ }^{(3)}$ は, 絶縁材料からの赤外線を赤外線温度検出器により計測し た。

本論文では，IEC が推奨するガラス板を用いた試験電極 ${ }^{(4)}$ で部分放電（以下，放電と呼称する）を発生させ，ポリエ チレンフィルム（以下，PEフィルムと呼称する）を部分放 電に暴露した。その結果, PE フィルムの形状変化は見出せ

\footnotetext{
日本大学短期大学部

T274-8501 船橋市習志野台 7-24-1

Nihon University Junior College
}

7-24-1, Narashinodai, Funabashi 274-8501
なかった。そこで, PEフィルムを水中で加熱処理した後, 室温において処理前後の試験片の寸法を比較したところ, $60^{\circ} \mathrm{C}$ 以上の熱処理温度で変化が始まった ${ }^{(5)}$ 。ここで用いた放 電電極による温度上昇は, $60^{\circ} \mathrm{C}$ 未満と考えられる。

部分放電に暴露された PEフィルムの温度を計測するため に, 結晶性高分子の温度因子を利用した。X 線回折装置の ゴニオメータに放電電極を取り付けて PEフィルムの温度を その回折強度より求めた。以下，これらについて記述する。

\section{2. 実験方法}

〈2・1〉試料吕エチレン樹脂は, 大倉工業(株)製の 低密度 PE フィルムを使用した。その性質は, 密度: $0.920 \mathrm{~g} / \mathrm{ml}$ (浮沈法, at $30^{\circ} \mathrm{C}$ ), 結晶化度 : $80.3 \%$ (X 線回折法), 分岐 数: 19 (赤外吸収法, $-\mathrm{CH} 3 / 1000 \mathrm{C}$ ), 厚さ: $0.095 \pm 0.005 \mathrm{~mm}$ （マイクロメータ,精度 $0.001 \mathrm{~mm}$ ）であった。つぎに, 温度特 性として熱変形温度 : $59.8^{\circ} \mathrm{C}$ （直交ニコル間で PE フィルム を暗黒に配置し, 温度を上昇させて直交ニコルが明るくな ったときの温度を呼称する), 融点 : $117^{\circ} \mathrm{C}$ (島津製作所製, 微量融点測定装置）のフィルムであった。測定結果のバラ ツキを少なくするために, 幅 $1 \mathrm{~m}$, 長さ $100 \mathrm{~m}$ のロールから 


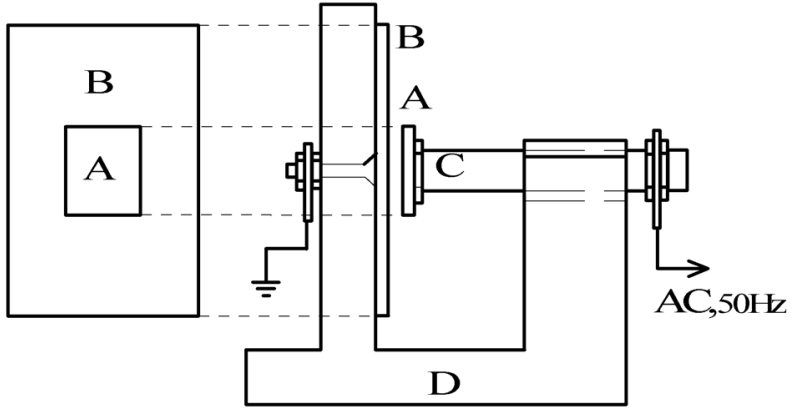

Fig. 1. The Composition of a partial discharge electrode.

長方形 $(\mathrm{M}$ 方向 $\times \mathrm{T}$ 方向 $=25 \mathrm{~mm} \times 40 \mathrm{~mm})$ に切り出した。 ただし， M 方向はフィルム製造時の巻き取り方向， $\mathrm{T}$ 方向 はフィルム面内で $\mathrm{M}$ 方向と直角な方向, フィルム厚さ方向 を $\mathrm{N}$ 方向と呼称する。

つぎに，フィルム表面の滑剤および油脂などの污れをエ タノールおよびベンゼンで洗浄した後, デシケータ内に入 れ，五酸化リン $\left(\mathrm{P}_{2} \mathrm{O}_{5}\right)$ で 24 時間乾燥した。

〈2·2〉 放電電極の構成＼cjkstart平行平板のガラス電極には 2 枚の導電性ガラス（旭ガラス製，厚さ： $1.78 \mathrm{~mm}$, ガラス の片面が導電性を持つ) を用いた。Fig.1の A,B はガラス電 極 $\left(\mathrm{A}: 11 \times 13 \mathrm{~mm}^{2}, \mathrm{~B}: 28 \times 43 \mathrm{~mm}^{2}\right)$ を示している。電極は導 電性面-ガラス-空隙-ガラス-導電性面を, 空隙間隔が $2.2 \mathrm{~mm}$ で平行に配置した。C は直径 $6 \mathrm{~mm}$ の真鍮円筒で交流電圧 $(50 \mathrm{~Hz})$ を $\mathrm{A}$ のガラス電極に伝え，一方の $\mathrm{B}$ のガラス電極を 接地した。これらの電極を構成するために電気絶縁性，耐 熱性および機械的強度の良好なガラスエポキシ樹脂(D)を用 いた。

〈2·3〉 ポリエチレンの回折強度測定 PE フィルムは 製造時にローラーで圧延され巻き取るため，その結晶軸は 配向している(5)。

測定の再現性を得るために PE フィルムは, M 方向を電極 面 B の短辺に合わせ，上部と下部をテフロンテープで弛ま ないように貼り付けた。

$\mathrm{X}$ 線は，その発生管（フィリップ社製，出力：1kW）の銅 電極（ターゲット）から生じる $\mathrm{K}_{\alpha}$ 線（波長 $\lambda=1.542 \AA ） の$ 単色光を用いた。Fig.2 は対称透過法の配置であり，エック ス線発生間のターゲットから生じた $\mathrm{X}$ 線が放電電極に入射 角 $\theta$ （放電電極面と $\mathrm{X}$ 線の中心線との間の角度）と反射角 （または散乱角）が等しくなるように配置した。空気中に放 出された X 線は，発散スリット（幅可変）から空気の分子 や原子によって散乱されて試料に到達し，そこで散乱され た X 線が受光スリット（幅固定）に集中した ${ }^{(6)}$ 後, 検出管 （GM 管）へ入射する。ポリエチレンの回折角は，ブラック の反射則により（110)，（200）および（020）のミラー面を もち，それぞれの $\theta$ が $10.83^{\circ} ， 12.03^{\circ}$ および $18.23^{\circ}$ であ った。

採用した（110）面の回折強度は他のミラー面よりも大き く $\theta$ がもっとも小さいため, PE フィルム面に多くの X 線 を入射することができる。Table 1 にX 線回折計の X 線発生

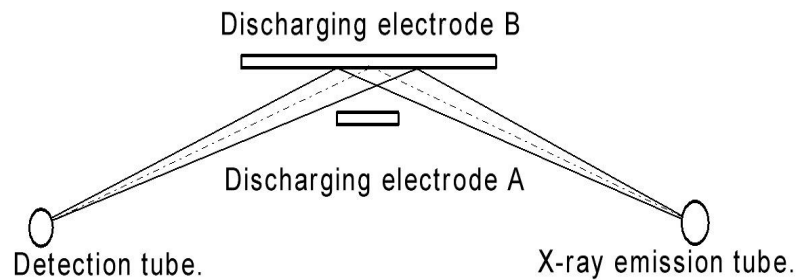

Fig. 2. The method of symmetrical reflection.

Table 1. Many conditions of the X-ray diffractometer.

\begin{tabular}{|c|c|}
\hline X-ray emission tube voltage. & D.C. $40 \mathrm{kV}$ \\
\hline X-ray emission tube current. & D.C. $10 \mathrm{~mA}$ \\
\hline Disvergence slit. & $0.5 \mathrm{~mm}$ (Varies.) \\
\hline Light reception slit. & $0.4 \mathrm{~mm}$ (Fixation.) \\
\hline Detection tube voltage. & D.C. $1.5 \mathrm{kV}$ \\
\hline Time constant. & $10 \mathrm{sec}$. \\
\hline
\end{tabular}

管電圧・電流, 発散スリット, 受光スリット, 検出管電圧, 時定数についての諸条件を示した。なお，ゴニオメータの 角度（精度 $0.01^{\circ} ）$ は水晶粉末によって校正した。

〈2·4〉 ポリェチレンの温度測定計測部以外の温度 の影響を低減するために, Fig.1 の放電電極をポリ塩化ビニ ル製のパイプ (内径 : $158 \mathrm{~mm}$, 肉厚 : $6 \mathrm{~mm}$, 高さ : $308 \mathrm{~mm}$ ) と平板のスレート（厚さ：5.5mm）によって覆った（容積 : $\left.6,039 \mathrm{~cm}^{3}\right)$ 。しかし，X 線はポリ塩化ビニルを透過しにくい ためにパイプの一部を切り取り, X 線を透過しやすい雲母 （厚さ：0.05mm）を空材料に使用した。さらに容器内の温度 を均一にするため, 容器内部にヒータとファンを設置した。

はじめに，室温時の回折強度を求め $2 \sim 5^{\circ} \mathrm{C}$ 上昇させ，そ の強度が 3 分間一定值を示した後, 室温へ戻した。それら の回折強度をチャート付きペングラフで記録した。温度の 調整範囲は $24 \sim 50^{\circ} \mathrm{C}$ であり, 試料面の温度をガラス封入サ ーミスタ温度計で計測した。

〈2.5〉放電時の温度測定＼cjkstart前述したポリエチレンの 温度測定で使用したヒータおよびファンを止め, サーミス タを取り外して室温に戻した。

放電を発生する条件は大気圧，空気中および室温として $50 \mathrm{~Hz}$ の交流電圧を $3 \mathrm{kV} \sim 7 \mathrm{kV}$ まで変化させた。

電圧の印加方法は $3 \mathrm{kV}$ を 5 分間加えて, 室温時の回折強 度が変化しないとき電圧を取り除いた。つぎに, 電圧を $3 \mathrm{kV}$ から $1 \mathrm{kV}$ ごとに高めて, 回折強度が減少したときはチャー 卜紙上で 5 分以上一定值を示した後に電圧を取り除いた。 その後, 室温に戻して回折強度が放電前の強度と一致した か否かを確認した。これらの回折強度の変化をチャート紙 上に記録した。

\section{3. 結 果}

〈3.1〉 PE フィルムの回折強度 PE フィルムの (110) 面の回折強度を得るために, X 線回折計のゴニオメータに 放電電極を Fig.2 のように固定した。PE フィルムへの照射 
面積は，発散スリット幅を $0.5 \mathrm{~mm}$ 開いたときに, PE フィル ム面上に幅 $5.32 \mathrm{~mm} \times$ 高さ $10.0 \mathrm{~mm}$ の蛍光塗料を塗った紙片 で計測することによって確認した。また，他のミラー面（例 えば,（200），(020），(002）面など）からの回折強度は (110) 面に比較して弱いことを確認した。

Fig. 3 に発散スリットを $0.5 \mathrm{~mm}$ に固定し, PE フィルムの 枚数とその回折強度特性を示した。〈2・2〉節で述べた放電 電極の構成で B のガラス電極に数枚のPEフィルムを重ねた 結果, 回折強度は 4 枚まで比例して増加した。5 枚以上の強 度は飽和傾向を示した。それらの回折強度の半值幅［回折 角 $\theta$ を $10 \sim 11.5^{\circ}$ の範囲で可変しながら回折強度図形を記 録し，(110)面の最大回折強度の 0.707 倍になる幅もも増加し た。

Fig.4 にガラス電極およびその電極に 1 枚の PE フィルム を貼り付けた各状態における発散スリット幅と（110）面の 回折強度特性を示した。図中の「ガラス電極」は，X 線が ガラス電極自身によって散乱された回折強度であり, 発散 スリット幅に比例した。「PE フィルム十ガラス電極」は 1 枚の PE フィルムを Fig.1 の B の電極面にテフロンテープで 貼り付けた測定結果で, その回折強度は $0.1 \sim 0.5 \mathrm{~mm}$ の発散

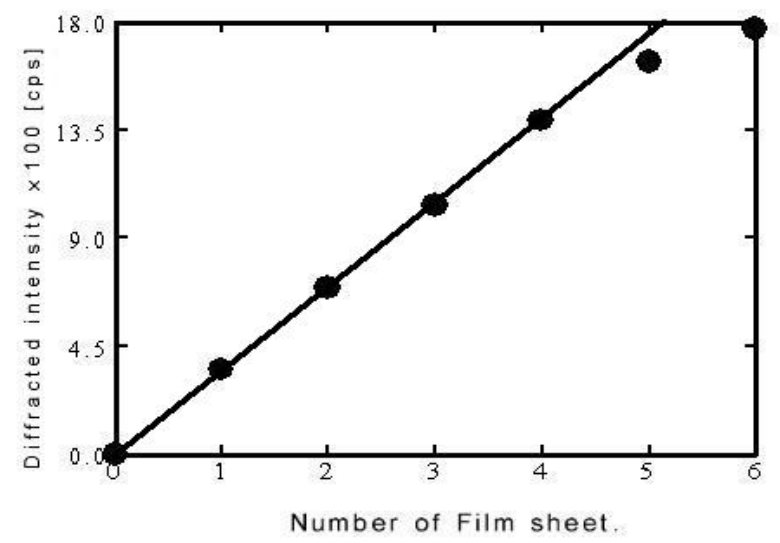

Fig. 3. Diffracted intensity of PE films.

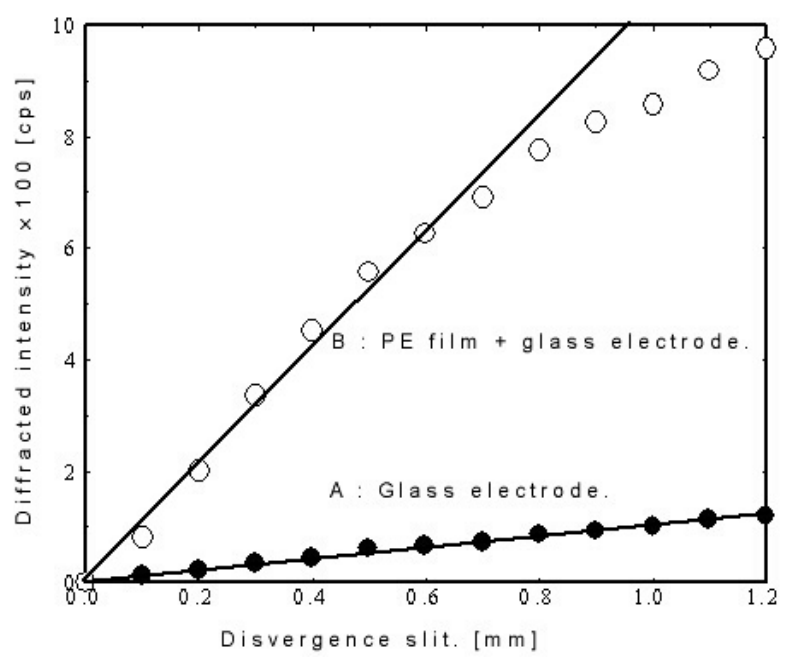

Fig. 4. Diffracted intensity of electrode \& PE film. スリット幅まで比例した。0.6mm 以上のスリットでは，飽 和する傾向を示した。なお, 図中の実線は比例関係を示す。 これらの結果から，1枚の PE フィルムで十分な X 線回折強 度を得られることが分かった。

〈3·2〉 放電時の PE フィルム温度 $\quad \mathrm{X}$ 線の発散スリ ットを $0.5 \mathrm{~mm}$ に固定し 1 枚の PE フィルムを使用して, つ ぎの結果が得られた。Fig.5にPEフィルム温度の回折強度と その時間特性を示した。550cps (counts per second) 付近の強 度は室温の值であり, $24^{\circ} \mathrm{C} \sim 40^{\circ} \mathrm{C}$ で温度を変化させた後, 室温に戻すとほぼ同じ值となった。つぎに, Fig.6 に回折強 度の温度特性を示した。Fig.5 で求めた各温度における回折 強度を示したもので, 室温から温度の上昇にともない減少 した。

Fig.7 に印加電圧と PE フィルムの回折強度変化を示した。 回折強度は印加電圧が $3 \mathrm{kV} \sim 5 \mathrm{kV}$ まで変化なく, $6 \mathrm{kV}$ およ び $7 \mathrm{kV}$ で減少した。室温時の回折強度は $550 \mathrm{cps}$ であり, $6 \mathrm{kV}$ および $7 \mathrm{kV}$ でのそれが 350cps であったので, Fig.6より判断 すると約 $16^{\circ} \mathrm{C}$ 温度上昇に相対していることがわかる。測 定に含まれる回折強度の変動（ペン先の振動）は $17 \mathrm{cps}$ 程度 であり, $0.8^{\circ} \mathrm{C}$ に相当した。また, Table 1 の時定数を $10 \mathrm{sec}$. から $1 \mathrm{sec}$.に変えることによって生じる温度幅は $0.8^{\circ} \mathrm{C}$ から

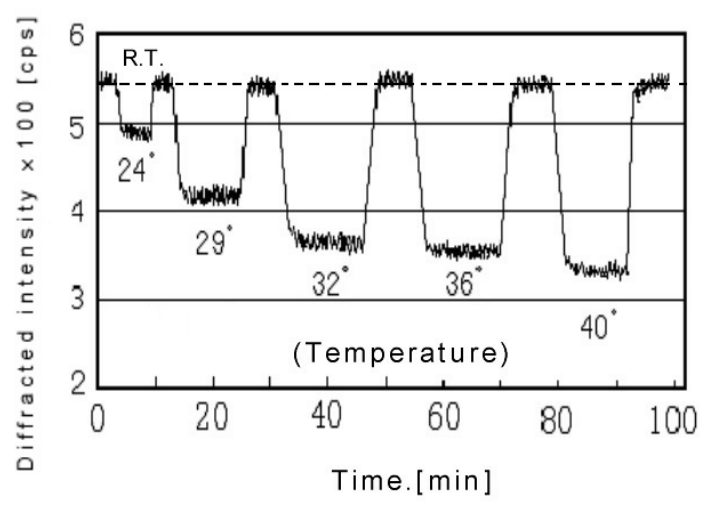

Fig. 5. Characteristics of diffracted intensity.

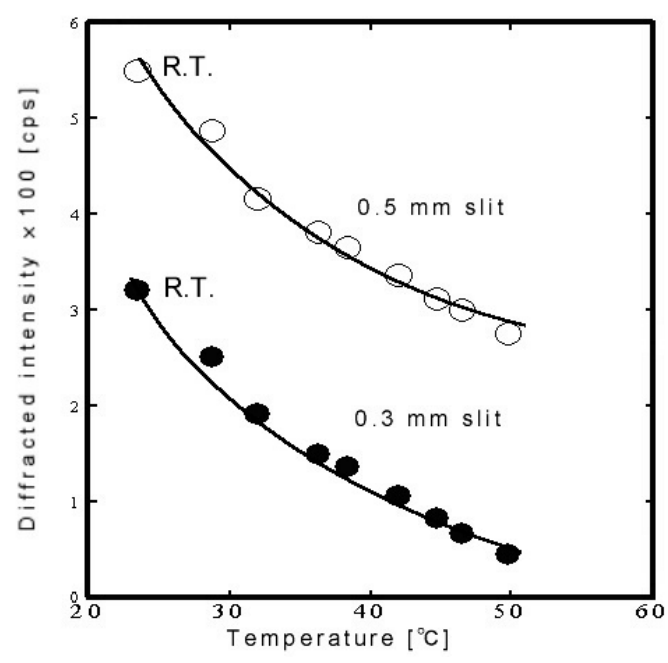

Fig. 6. Temperature characteristics of diffracted intensity. 


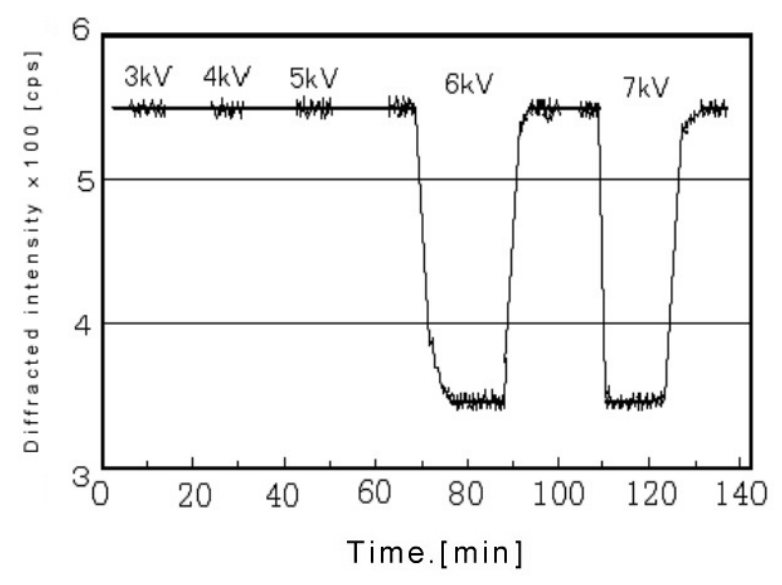

Fig. 7. Characteristics of voltages vs. X-Ray diffracted intensity.

$1.8^{\circ} \mathrm{C}$ 変わった。

回折強度は $6 \mathrm{kV}$ と $7 \mathrm{kV}$ で減少し, 放電を止めると室温時 の強度に戻った。また, $7 \mathrm{kV}$ の放電による温度上昇変化が $6 \mathrm{kV}$ よりも早かった。

\section{4. 考 察}

〈4·1〉 ポリエチレンの回折強度 PE フィルムの （110）面の回折強度は, Fig.3 より 4 枚までが枚数に比例し ながら増加した。これはX 線が PE フィルム内を透過しやす いためと考えられる。回折強度の増加は高感度な測定を可 能にする。しかし，ポリエチレン樹脂の熱伝導率が約 0.34 $\left[1 / \mathrm{W} \cdot \mathrm{m}^{-1} \cdot \mathrm{K}^{-1}\right]$ と低いために多数のフィルムを重ねるより も，1枚のフィルムで測定することが良いと考える。

PE フィルムを 5 枚以上重社た回折強度は飽和する傾向を 示した。その傾向を示すのは，〈3・1〉節で記したように （110）の半值幅が広がったことにより，表面およびガラス 電極に接するフィルム面からの散乱 X 線が受光スリットで 収束しなくなったためと考えられる。

ガラス電極自身の回折強度（Fig.4）はガラスが非晶質で あり，特定の回折角に鋭いピークを持たない散漫散乱 X 線 であるため発散スリット幅に比例したと考えられる。

ガラス電極に 1 枚の PE フィルムを貼り付けて発散スリッ ト幅を変えた場合, その回折強度は $0 \sim 0.5 \mathrm{~mm}$ の発散スリッ 卜幅まで比例し，0.6 $\mathrm{mm}$ 以上で飽和する傾向を示した。この 飽和する傾向は Fig.1, Fig.2 より, A-B 電極間隔 $(2.2 \mathrm{~mm})$ と $\mathrm{A}$ 電極の幅 $(11 \mathrm{~mm})$ が $\mathrm{X}$ 線発生管より発散された $\mathrm{X}$ 線 を遮蔽するか, あるいはフィルム面からの散乱 X 線が受光 スリットで収束しなくなるためと考えられる。

〈4·2〉 PE フィルムの温度因子 PE 分子鎖は炭素原 子の共有結合であり，分子鎖閒の結合はファン・デル・ワ ールスカである。それらの原子は平衡位置を中心に熱振動 している。Fig.6より, 加熱中の回折強度が室温時よりも減 少するのは, 温度の上昇に伴って原子閒の距離が微小変位 するためである。熱振動による回折強度の減少は高い温度 ほど，回折角が大きく高次反射ほど大きくなる。さらに，

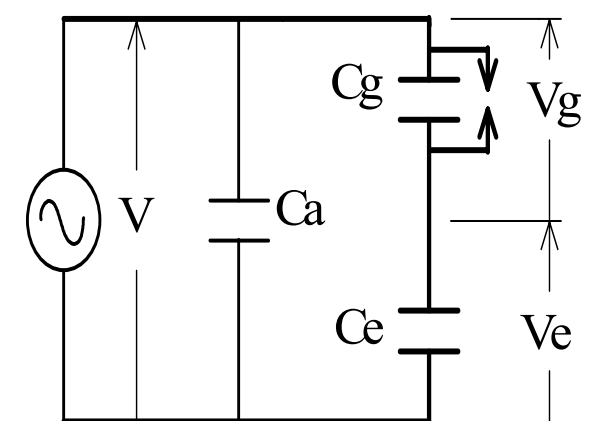

Fig. 8. Equivalent circuits of partial discharged electrode.

熱振動によって（110）面の回折角を中心に幅広い散乱にな る (熱散漫散乱)。熱振動による効果は原子散乱因子とデバ イ・ワーラー因子（あるいは温度因子）の積になることが 知られている(7)

この結果, 熱処理後に室温の回折強度に戻るのは, 熱に よって結晶質の分子は振動するが, 結晶質のPE の分子鎖が 流動しなかったためと考えられる。

〈4・3〉放電によるポリエチレンの温度特性 部分放 電に暴露された PE フィルムの温度変化は, 回折強度の変化 として現れた。発散スリットを $0.5 \mathrm{~mm}$ に固定したときの回 折強度は温度の上昇に伴って減少した。放電による温度上 昇が回折強度を減少させる印加電圧は $6 \mathrm{kV}$ と $7 \mathrm{kV}$ であり, 到達する温度は同じであった。しかし, その温度に至る時 間は $7 \mathrm{kV}$ が早かった。一般的に高い印加電圧において, よ り多くの放電を生じる。そこで放電電極に加わる電圧を等 価回路より求めた（Fig.8）。

ここで $C_{a}$ を電極周り， $C_{e}$ を 1 枚のガラス， $C_{g}$ を電極間の 静電容量, それぞれの比誘電率を $\varepsilon_{a}$ および $\varepsilon_{e}, \varepsilon_{g}$ とした。 印加電圧を $V$ とおくと, 電極間のギャップに加わる電圧 $V_{g}$ は(1)式となる。

$$
V_{g}=\frac{V C_{e} / 2}{C_{g}+C_{e} / 2}[\mathrm{~V}] \text {. }
$$

また，非対称の電極面積を等しく，ガラスの厚さとギャ ップ長を $d_{e}, d_{g}$ とするとギャップ間電圧 $V_{g}$ は, $(2)$ 式に置 き換えられる。

$$
V_{g}=\frac{V \varepsilon_{e} / 2 d_{e}}{\varepsilon_{g} / d_{g}+\varepsilon_{e} / 2 d_{e}} \quad[\mathrm{~V}]
$$

この式に $, d_{g}=2.20 \mathrm{~mm}, d_{e}=1.78 \mathrm{~mm}, \varepsilon_{g}=1.00, \varepsilon_{e}=8.85$ を 代入するとギャップ間電圧 $V_{g}$ は, $(3)$ 式となる。

$$
V_{g}=0.99 \mathrm{~V} \quad[\mathrm{~V}]
$$

放電によってPEフィルム温度が上昇した前後の印加電圧 $V$ とギャップ間電圧 $V_{g}$ および電界の強さ $E_{g}$ の関係を Table 2 に示す。この表より, 大気圧中で放電が開始する電界の強 さは $3 \mathrm{kV} / \mathrm{mm}$ であるから, $V=6 \mathrm{kV}$ 以上の電圧を印加すれば 部分放電が開始する。しかし，この開始電圧では温度上昇 が見出せなかったことから, 温度上昇が検出できないほど 小さいことが考えられる。

$V=6 \mathrm{kV}$ 以上の電圧では放電による電離度が高くなり，ポ 
Table 2. Relationship applied voltages and discharge voltages.

\begin{tabular}{|c|c|c|}
\hline $\begin{array}{c}V \\
{[\mathrm{kV}]}\end{array}$ & $\begin{array}{c}V_{g} \\
{[\mathrm{kV}]}\end{array}$ & $\begin{array}{c}E_{g} \\
{[\mathrm{kV} / \mathrm{mm}]}\end{array}$ \\
\hline 4.00 & 3.96 & 1.80 \\
\hline 5.00 & 4.95 & 2.45 \\
\hline 6.00 & 5.94 & 2.94 \\
\hline 7.00 & 6.93 & 3.43 \\
\hline
\end{tabular}

リエチレンの温度が上昇したと考えられる。ただし，V= $6 \mathrm{kV}, 7 \mathrm{kV}$ の温度上昇が等しいことはつぎの二つの事項が考 えられる。

(1) 高電圧によってさらに電離度が増し,電離したイオ ン同士が衝突するためにフィルムの温度がほぼ等しくなっ た。

(2) 電極の導電面が電極端まであるため, 電極端に放電 が集中して放電電極下における電離度は変わらないために 電圧の上昇に対してフィルム温度が変わらなかった。

放電電極の下で部分放電に暴露されたポリエチレンの温 度上昇は約 $16^{\circ} \mathrm{C}$ であった。Fig.5 の指針（ペン先）の振動は $17 \mathrm{cps}$ であり, その振動はX 線の不連続性によるもので Table 1 の時定数を $10 \mathrm{sec}$. から $1 \mathrm{sec}$.に変えることによって約 $0.8^{\circ} \mathrm{C}$

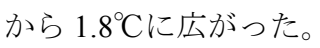

部分放電に暴露された電気絶縁材料の温度を計測する方 法には, IEC の棒一平板電極（空気の閒隙を持たない電極構 成）を用いた 2 つの方法が報告されている。Ahmed ら ${ }^{(2)}$ は 絶縁材料内に熱電対を埋設して求めた。平林ら ${ }^{(3)}$ は絶縁材料 からの赤外線を赤外線温度検出器により計測した。これら の室温より上昇する温度は印加電圧を高めると, より高温 になっている。

本論文の温度上昇は印加電圧を高めても一定の温度を示 した。使用した電極は面積の異なるガラス平行平板電極で 空気の間隙を有する点が異なる。その原因は，イオンの電 離度や放電が放電電極の端で発生しや寸いエッジ効果が考 えられる。

\section{5. むすび}

部分放電電極を X 線回折計のゴニオメータに設置して, ポリエチレンフィルムの回折強度変化から放電による温度 上昇を計測した。ポリエチレンの X 線回折強度は（110）面 がもっとも大きく, その回折強度は加熱によって減少する。
加熱によってポリエチレン分子鎖が移動すると室温時の回 折強度が変化するため, 室温時の強度が変わらないことを 確認しながら計測した結果，つぎの事柄が判明した。

（1） X 線はポリエチレンフィルムを透過するため, その 表面および内部に区別なく平均的な温度を測定した。

（2）この温度測定方法はポリエチレンフィルムの熱変 形温度以内 $\left(60^{\circ} \mathrm{C}\right.$ 未満 $)$ であれば非接触で再現できる。

今後は, ここで用いた放電電極の X 線照射面とエッジの 電離度を計測したいと考えている。終わりに, ご指導いた だきました日本大学名誉教授 山本 滋 先生に深く感謝い たします。

(平成 18 年 11 月 20 日受付, 平成 19 年 4 月 27 日再受付)

\section{文献}

（1）堀井憲爾・藤 幸生：「固体絶縁物のエアギャップ中におけるコロナ 放電の発光スペクトルの測定」, 電気学会雑誌, Vol.86-4, No.931, pp.591-595 (1966-4)

(2) F. S. Ahmed : "Breakdown of Solid Insulating Films by Partial Discharge, Using Sinusoidal and Pulse Voltages.", IEEE Trans. EI, Vol.13, No.5, pp.337-342 (1978)

(3) 平林庄司・永田秀次 - 平沢栄一 · 犬石嘉雄 $\cdot$ 長谷川武敏 :「部分放電 劣化試験における電圧および周波数加速限界の検討」, 電学論 $\mathrm{A}$, Vol.100-A, No.6, pp.345-352 (1980-6)

(4) 例えば, 電気学会編 : 放電ハンドブック,p.480 オーム社

(5) 早川朝康・黄 明煥・山本 滋:「低密度ポリエチレンフィルムの結 晶部, 非晶部の配向について」, 電学論 A, Vol.103-A, No.12, pp.43-50 (1983-12)

(6) 高良和武：「X 線回折」, 実験物理学講座 20,p.117, 共立出版 (1988)

(7) 菊田惺志: 「X 線回折・散乱技術上」, 物理工学実験 $15, \mathrm{p} .103$, 東京 大学出版会 (1992)

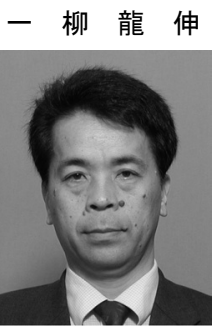

（正員） 昭和 32 年 9 月 11 日生。昭和 57 年 3 月日本大学大学院理工学研究科博士前期課程 修了。昭和 57 年 4 月日本大学短期大学部工業 技術学科助手, 現在に至る。主として電気計測 および絶縁材料の部分放電，材料の性質に関す る研究に従事。

早 川 朝 康 (正員) 昭和 25 年 8 月 12 日生。昭和 51 年 3

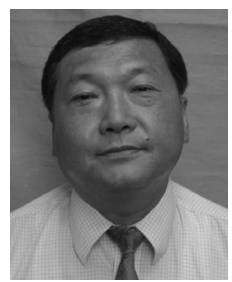
月日本大学大学院理工学研究科修士課程修了。 平成 5 年 4 月 日本大学短期大学部工業技術学科 専任講師, 現在同大短期大学部基礎工学科に名 称変更。博士 (工学)。主として高分子絶縁材 料の部分放電, 高分子材料の光学的性質に関す る研究に従事。 